\title{
Participation of Heart Mitochondria in Myocardial Protection Against Ischemia/Reperfusion Injury: Benefit Effects of Short-Term Adaptation Processes
}

\author{
M. FERKO ${ }^{1}$, I. KANCIROVÁ ${ }^{1}$, M. JAŠOVÁ ${ }^{1}$, I. WACZULÍKOVÁ ${ }^{2}$, S. ČARNICKÁ C̆ $^{1}$ \\ J. KUCHARSKÁ ${ }^{3}$, O. ULIČNÁ ${ }^{3}$, O. VANČOVÁ ${ }^{3}$, M. MURÁRIKOVÁ ${ }^{1}$, \\ T. RAVINGEROVÁ ${ }^{1}$, A. ZIEGELHÖFFER ${ }^{1}$
}

${ }^{1}$ Institute for Heart Research, Slovak Academy of Sciences, Centre of Excellence of SAS NOREG, Bratislava, Slovakia, ${ }^{2}$ Department of Nuclear Physics and Biophysics, Faculty of Mathematics, Physics and Informatics, Comenius University, Bratislava, Slovakia, ${ }^{3}$ Pharmacobiochemical Laboratory, Third Department of Internal Medicine, Faculty of Medicine, Comenius University, Bratislava, Slovakia

Received March 25, 2015

Accepted July 17, 2015

On-line December 15, 2015

\section{Summary}

Acute streptozotocin diabetes mellitus (DM) as well as remote ischemic preconditioning (RPC) has shown a favorable effect on the postischemic-reperfusion function of the myocardium. Cardioprotective mechanisms offered by these experimental models involve the mitochondria with the changes in functional properties of membrane as the end-effector. The aim was to find out whether separate effects of RPC and DM would stimulate the mechanisms of cardioprotection to a maximal level or whether RPC and DM conditions would cooperate in stimulation of cardioprotection. Experiments were performed on male Wistar rats divided into groups: control, DM, RPC and DM treated by RPC (RPC+DM). RPC protocol of 3 cycles of 5-min hind limb ischemia followed by 5 -min reperfusion was used. Ischemicreperfusion injury was induced by $30-\mathrm{min}$ ischemia followed by 40-min reperfusion of the hearts in Langendorff mode. Mitochondria were isolated by differential centrifugation, infarct size assessed by staining with $1 \%$ 2,3,5-triphenyltetrazolium chloride, mitochondrial membrane fluidity with a fluorescent probe $\mathrm{DPH}, \mathrm{CoQ}_{9}$ and $\mathrm{CoQ}_{10}$ with HPLC. Results revealed that RPC as well as DM decreased the infarct size and preserved mitochondrial function by increasing the mitochondrial membrane fluidity. Both used models separately offered a sufficient protection against ischemic-reperfusion injury without an additive effect of their combination.

\section{Key words}

Remote ischemic preconditioning - Acute streptozotocin diabetes mellitus • Heart mitochondria • Membrane fluidity • Infarct size

\section{Corresponding author}

M. Ferko, Institute for Heart Research, Slovak Academy of Sciences, Dúbravská cesta 9, P.O. Box 104, 84005 Bratislava 45, Slovak Republic. E-mail: usrdmife@savba.sk

\section{Introduction}

Both acute streptozotocin-induced diabetes mellitus (DM) and remote ischemic preconditioning (RPC) represent a suitable model for investigation of adaptive mechanisms leading to the increase of ischemic tolerance and to the reduction of extent of ischemic-reperfusion injury in the myocardium (Ferdinandy et al. 2014, Przyklenk et al. 1993, Ravingerová et al. 2000, Tosaki et al. 1996). The rationale for studying the experimental models is based on the established knowledge of the cardioprotection method induced by ischemic preconditioning. RPC, which is induced by short ischemic and reperfusion periods on a distant tissue such as a limb, prevents myocardial ischemic-reperfusion injury by the activation of humoral (Lim et al. 2010), neural (Mastitskaya et al. 2012) and/or systemic pathways 
involving crosstalk with immune cells (Przyklenk and Whittaker 2011). Up-regulation of survival signal pathway converges on the mitochondria as an RPC end-effector (Veighey and MacAllister 2012). Preconditioning (PC)-like protection observed in the experimental model of streptozotocin-induced DM was manifested in the acute phase of the disease, when the alterations caused by complications are not fully developed (Ravingerová et al. 2000). Increased resistance to ischemia of the diabetic myocardium is attributed to the alterations in the function of subcellular structure and metabolism of cardiac cells including resistance to $\mathrm{Ca}^{2+}$ overload (Tani and Neely 1988, Tribulová et al. 1996), formation of mitochondrial permeability transition pores (mPTP) (Bakker et al. 1993, Ziegelhöffer-Mihalovičová et al. 1997) and remodelation of sarcolemmal (Ziegelhöffer-Mihalovičová et al. 2003) and mitochondrial membranes (Ferko et al. 2008) associated with the change in their fluidity. Apparently, the membrane fluidity seems to be critical to the function and adaptation of cardiomyocytes thus forming a part of the process of the endogenous protective mechanisms. The concept of fluidity as applied to membranes usually refers to a molecular mobility and ordering of phospholipid acyl chains inside the lipid bilayer. Fluidity essentially depends on the protein and lipid composition, especially on the cholesterol-to-phospholipid content, as well as on the extent of free radicals-induced lipid peroxidation (Waczulíková et al. 2010). In diabetic rat hearts, the sarcolemmal membrane was proved to be less fluid owing to nonenzymatic glycosylation of membrane biomolecules which, on the other hand, protects the myocardium against $\mathrm{Ca}^{2+}$ overload (Ziegelhöffer-Mihalovičová et al. 2003). Unlike the sarcolemma, mitochondrial membrane, exhibits an increased fluidity thus improving ATP transport from the mitochondrial matrix into the cytosol of the cardiomyocytes. Such a positive fluidising effect observed in DM (Ferko et al. 2008), in the mitochondrial membrane could also be observed in the protective mechanism induced by RPC (Ferko et al. 2014). The described cardioprotective effect of RPC and PC-like protection have usually been accompanied by a reduced infarct size (Heusch 2015, Ravingerová et al. 2010). The presented paper is aimed to verify whether RPC and DM separately would offer a maximal possible cardioprotective effector and whether they would cooperate in stimulation of cardioprotection. For this purpose the simultaneous action of streptozotocin-induced DM and RPC has been investigated with the attention focused on the functional properties of mitochondrial membrane, i.e. membrane fluidity and formation of oxidized form of coenzyme Q (CoQ). At the same time, the postischemic-reperfusion functional properties of myocardium were investigated by measuring the myocardial infarct size.

\section{Methods}

Animals

Male Wistar rats (9-11 weeks old, $220 \pm 20 \mathrm{~g}$ b. wt.) were used for this study. They were randomly divided into four groups of seven animals each to form a control group (C), a diabetic group (DM), a remote ischemic preconditioning group (RPC) and a diabetic group treated by remote ischemic preconditioning (DM+RPC). All animals were kept under the standard light regimen (D:L, 12:12) at $22 \pm 2{ }^{\circ} \mathrm{C}$ in a cage (max 5 animals per cage) with access to water and to a standard pellet food ad libitum. All experiments were performed in accordance with the Guide for the Care and Use of Laboratory Animals published by the US National Institutes of Health (NIH Publication No. 85-23, revised 1996) and were approved by the Animal Health and Animal Welfare Division of the State Veterinary and Food Administration of the Slovak Republic.

\section{Induction of diabetes mellitus}

Acute diabetes mellitus was induced by a single dose of streptozotocin $\left(65 \mathrm{mg} \cdot \mathrm{kg}^{-1}\right.$, i.p.) dissolved in 0.1 mol. $^{-1}$ citrate buffer, $\mathrm{pH} 4.0$. Diabetic state of rats was monitored daily during eight days by measuring of glycosuria using Gluko PHAN strips (Erba-Lachema, Brno, Czech Republic) and by estimation of glucose after excision of heart (MultiCare, Biochemical system international, Florence, Italy) and glycohemoglobin (BIO-LA-TEST, GHB 100, Pliva-Lachema, Brno, Czech Republic) in the blood, as well as cholesterol and triacylglycerols (MultiCare, Biochemical system international, Florence, Italy) in the serum. Serum insulin was determined by the commercial RIA kit (Linco Research USA).

\section{Induction of remote ischemic preconditioning}

Animals were anesthetized by intraperitoneal injection of thiopental (50-60 mg. $\left.\mathrm{kg}^{-1}\right)$ administered together with heparin (500 IU). RPC was evoked by inflation (to $200 \mathrm{~mm} \mathrm{Hg}$ ) of pressure-cuff placed around the right hind limb followed by cuff deflation. This intervention led to cessation and renewal of the blood flow in descending branches of the femoral artery. RPC 
protocol of 3 cycles of $5 \mathrm{~min}$ hind limb ischemia followed by $5 \mathrm{~min}$ of reperfusion was used.

\section{Perfusion of the isolated heart}

After anesthetization of the animals (as described in the previous paragraph) and opening the chest cavity, hearts were rapidly excised, placed in icecold perfusion buffer and Langendorff perfused with oxygenated $\left(95 \% \mathrm{O}_{2}\right.$ and $5 \% \mathrm{CO}_{2}$ ) Krebs-Henseleit buffer containing (in $\mathrm{mM}$ ): $\mathrm{NaCl} 118, \mathrm{KCl} 3.2, \mathrm{MgSO}_{4}$ 1.2, $\mathrm{NaHCO}_{3} 25, \mathrm{NaH}_{2} \mathrm{PO}_{4} 1.18, \mathrm{CaCl}_{2} 2.5$, glucose 11.1, $\mathrm{pH} 7.4$ at $37^{\circ} \mathrm{C}$. Perfusion was maintained at a constant pressure of $70 \mathrm{~mm} \mathrm{Hg}$ and perfusion protocol consisted of $25 \mathrm{~min}$ stabilization perfusion, $30 \mathrm{~min}$ global ischemia and $40 \mathrm{~min}$ of post-ischemic reperfusion. Isolated hearts of all groups were taken at the end of each stage of perfusion protocol for further investigation. For the investigation of mitochondrial processes utilized in the present study, the model of global ischemia is more appropriate for technical reasons. While in the model of regional ischemia, left anterior descending (LAD) occlusion, ischemic (risk) area represents approximately $40 \%$ of the size of the left ventricle, in the model of global ischemia, the whole heart is ischemic.

\section{Isolation of mitochondria}

Isolated hearts were cut into small pieces by scissors and damped with small volume of ice-cold isolation solution (IS, containing in $\mathrm{mmol}^{-1}$ : $180 \mathrm{KCl}$, 4 EDTA, $1 \%$ bovine serum albumin, $\mathrm{pH}$ 7.4). Minced tissues of hearts were suffused with $20 \mathrm{ml}$ of ice-cold IS with addition of protease $2.5 \mathrm{mg} . \mathrm{g}^{-1}$ of tissue (Sigma P-6141) and mild stirred for $20 \mathrm{~min}$. Subsequently tissues were homogenized gently in teflon/glass homogenizer for 2-3 min. After $10 \mathrm{~min}$ centrifugation at $1000 \mathrm{~g}$ the obtained supernatant together with the part of mitochondria, which were in direct contact with protease, was poured out. Pellet containing mitochondria was homogenized again in the same volume of ice-cold IS without protease and spunned down as previously. Obtained supernatant containing predominantly mitochondria was centrifugated at $6200 \mathrm{~g}$ for $10 \mathrm{~min}$ and pellet was re-suspended again in an albumin free isolation solution (IS, containing in mmol.1 ${ }^{-1}: 180 \mathrm{KCl}, 4$ EDTA). The final mitochondrial fraction was spun down at $6200 \mathrm{~g}$ for $10 \mathrm{~min}$ and subsequently used for estimation of protein concentration according to Lowry et al. (1951) as well as for further biophysical and biochemical investigations. The whole isolation procedure was performed at $4{ }^{\circ} \mathrm{C}$.

\section{Membrane fluidity}

For evaluation of the membrane fluidity of isolated heart mitochondria the parameter of steady-state fluorescence anisotropy of a lipophilic fluorescent probe 1,6-diphenyl-1,3,5-hexatriene (DPH, Sigma-Aldrich) (Incerpi et al. 1988) was used. A degree of steady state DPH fluorescence anisotropy characterizes the mobility of phospholipid acyl chain in the lipid bilayer of a membrane and is inversely proportional to membrane fluidity (Shinitzky 1984). For DPH measurements, mitochondria were resuspended in an isotonic buffer containing $\mathrm{KCl} 180 \mathrm{mmol.} \mathrm{l}^{-1}$, EDTA $4 \mathrm{mmol}^{-1}$ (adjusted to $\mathrm{pH}$ 7.4) at a level at which no significant light scattering had been recorded $\left(10 \mathrm{mg} \cdot \mathrm{ml}^{-1}\right)$. Diluted mitochondrial suspension was subsequently labeled with a $0.25 \mu \mathrm{mol} .1^{-1}$ solution of DPH and stored at $30 \pm 0.2{ }^{\circ} \mathrm{C}$ in the dark for 20 min to allow a complete incorporation of the probe molecules into the membranes. Steady-state fluorescence anisotropy was measured with a luminescence spectrometer LS 45 (Perkin Elmer, USA) with the excitation wavelength set at $360 \mathrm{~nm}$ and with the wavelength of $425 \mathrm{~nm}$ for detection of emission. Fluorescence anisotropy of DPH as an indicator inversely proportional to the membrane fluidity was determined as the mean of at least ten consecutive recordings.

\section{Determination of coenzyme $Q\left(\operatorname{Co}_{9_{-o x}}\right.$ and $\left.\operatorname{Co} Q_{10-o x}\right)$}

Content of oxidized isoforms of coenzyme $\mathrm{Q}$ $\left(\mathrm{CoQ}_{9-\mathrm{ox}}\right.$ and $\left.\mathrm{CoQ}_{10-\mathrm{ox}}\right)$ in the isolated mitochondria was estimated by means of high pressure liquid chromatography (HPLC, Beckmann Gold, USA) using a 250 x $4 \mathrm{~mm}$ i.d., $7 \mu \mathrm{m}$ sephadex column (Sepharon SGXC18, Tessek, Czech Republic). The mobile phase consisted of the mixture methanol : acetonitrile : ethanol 6:2:2 and was applied at a flow ratio of $1 \mathrm{ml} . \mathrm{min}^{-1}$; sample volume of $20 \mu \mathrm{l}$. Concentration of coenzyme isoforms was detected spectrophotometrically at the wavelength of $275 \mathrm{~nm}$. All measurements were performed at room temperature. For more details see Kucharská et al. (1996).

\section{Infarct size determination}

The infarct size (IS) area was delineated by staining with $1 \%$ 2,3,5-triphenyltetrazolium chloride dissolved in 0.1 M phosphate buffer ( $\mathrm{pH}$ 7.4). The hearts were cut perpendicularly to the long axis of the ventricle into the $1 \mathrm{~mm}$ thick slices and stored overnight in $10 \%$ 
neutral formaldehyde solution. IS was determined by a computerized planimetric method as described earlier (Ravingerová et al. 2007) and was expressed as a percentage of the area at risk (AR) size.

\section{Statistical analysis}

Data were checked for normality with the Shapiro-Wilk W-test. Precision of the estimated mean was evaluated by standard error. Effect of treatment (stabilized, ischemic, reperfused) within the given group was tested with one-way analysis of variance, followed either with the Dunnett test for multiple comparisons with the control or with the Tukey-Kramer test for all pairwise comparisons. In the case of non-normality and/or unequal variances among groups being compared, a nonparametric alternative (the Kruskal-Wallis test and the post hoc pairwise comparisons with the Connover-Inman test) were performed. The effects within the same level of treatment were analyzed with the unpaired t-test, if not otherwise stated. All statistical analyses were performed using StatsDirect version 2.7.8 (StatsDirect, UK).

Table 1. Metabolic parameters of rats with experimental streptozotocin-induced diabetes mellitus.

\begin{tabular}{lcc}
\hline & $\begin{array}{c}\text { Control } \\
\text { group }\end{array}$ & $\begin{array}{c}\text { Diabetic } \\
\text { group }\end{array}$ \\
\hline Glucose (mmol. $\left.{ }^{-1}\right)$ & $5.19 \pm 0.14$ & $17.94 \pm 0.86^{*}$ \\
Triacylglycerols $\left(g . l^{-1}\right)$ & $1.27 \pm 0.11$ & $4.54 \pm 0.37^{*}$ \\
Cholesterol $\left(\right.$ g. $\left.l^{-1}\right)$ & $1.73 \pm 0.10$ & $2.65 \pm 0.12^{*}$ \\
Glycohemoglobin $(\% H b)$ & $4.09 \pm 0.10$ & $7.62 \pm 0.96^{*}$ \\
Insulin $\left(\right.$ ng.ml $\left.l^{-1}\right)$ & $1.08 \pm 0.18$ & $0.48 \pm 0.07^{*}$ \\
\hline
\end{tabular}

Results are given as means \pm SEM; $n=12, * \mathrm{p}<0.01$ diabetic vs. control group.

\section{Results}

In order to investigate a potential simultaneous impact of streptozotocin-induced DM and RPC on the postischemic-reperfusion functional properties of myocardium and its subcellular organelles mitochondria the myocardial infarct size area and mitochondrial membrane fluidity was measured and the content of coenzyme $\mathrm{Q}$ in oxidized form was determined. The main purpose of this study was to assess whether the experimental model of acute streptozotocin-induced DM and RPC separately would offer cardioprotection in a higher level or whether their simultaneous action would result in the additive effect in cardioprotection.

Diabetic state of experimental animals was confirmed by a significant $(p<0.01)$ increase in blood glucose, triacylglycerols, cholesterol and content of glycohemoglobin as well as in a decrease in blood levels of insulin (Table 1).

The results shown in Figure 1 represent the infarct size normalized to the size of the left ventricle from control, diabetic, RPC and RPC+DM group. In the diabetic rats, the IS/LV was smaller $(46.19 \%)$, but did not differ significantly from RPC rats $(35.26 \%)$. The protective combined effect of DM and RPC was also observed (decrease in IS/LV by $35.8 \%$ ), but was less explicit compared to RPC and diabetic group affected separately.

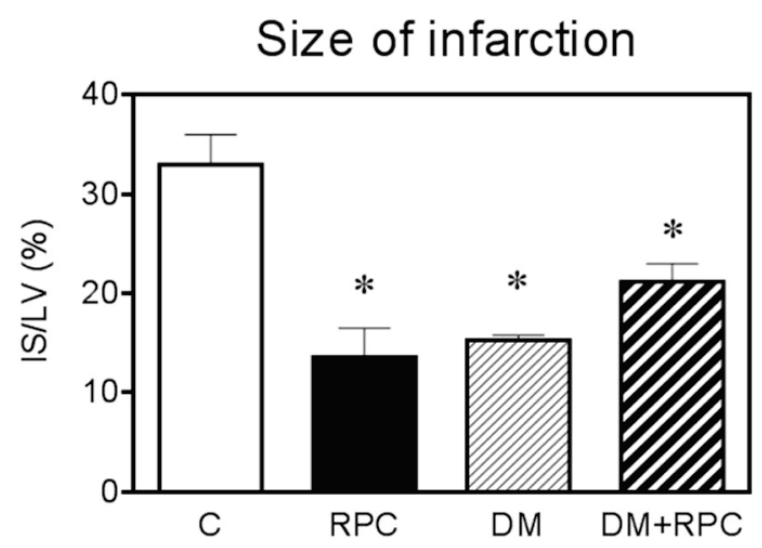

Fig. 1. Effect of RPC and DM on the size of myocardial infarction. $\mathrm{C}$ - control group; RPC - remote ischemic preconditioning; DM diabetes mellitus, $* \mathrm{p}<0.05 \mathrm{RPC}$, DM and DM+RPC vs. C

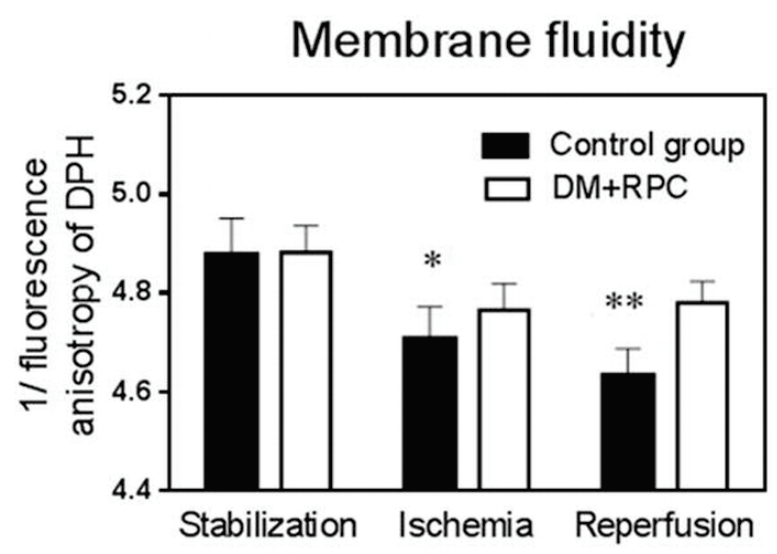

Fig. 2. Effect of DM with RPC on mitochondrial membrane fluidity (inversely proportional to the fluorescence anisotropy of $\mathrm{DPH})$. Results are given as means $\pm \mathrm{SEM}, \mathrm{n}=8$. $C-$ control group, DM+RPC - group of streptozotocin-induced d. mellitus affected by remote ischemic preconditioning. $* \mathrm{p}<0.05 \mathrm{C}$ after $30 \mathrm{~min}$ ischemia vs. C after $15 \mathrm{~min}$ of stabilization perfusion, $* * \mathrm{p}<0.01 \mathrm{C}$ after $40 \mathrm{~min}$ reperfusion vs. C after $15 \mathrm{~min}$ of stabilization perfusion 
Table 2. Changes in the functional properties of rat heart mitochondria induced by DM-, RPC-, RPC+DM-caused remodeling.

$\begin{array}{lll}\text { Stabilization } & \text { Ischemia } & \text { Reperfusion }\end{array}$

\begin{tabular}{|c|c|c|c|}
\hline \multicolumn{4}{|c|}{ Fluidity of mitochondrial membrane [arb. unit] } \\
\hline C & $4.88 \pm 0.07$ & $4.71 \pm 0.06$ & $4.63 \pm 0.05$ \\
\hline$D M$ & $5.08 \pm 0.06$ & $4.72 \pm 0.04$ & $4.71 \pm 0.04$ \\
\hline$R P C$ & $4.99 \pm 0.04$ & $4.90 \pm 0.05^{*}$ & $4.87 \pm 0.07^{\# \#}$ \\
\hline$R P C+D M$ & $4.88 \pm 0.05$ & $4.76 \pm 0.05$ & $4.78 \pm 0.04$ \\
\hline \multicolumn{4}{|c|}{ Content of oxidized form of coenzyme $Q_{9}$ in mitochondria [nmol/mg of protein] } \\
\hline C & $2.60 \pm 0.09$ & $3.72 \pm 0.33^{++}$ & $3.02 \pm 0.17$ \\
\hline$D M$ & $3.48 \pm 0.49^{++}$ & $4.08 \pm 0.26$ & $3.66 \pm 0.24^{\#}$ \\
\hline$R P C$ & $3.42 \pm 0.23^{+}$ & $3.34 \pm 0.29$ & $3.04 \pm 0.22$ \\
\hline$R P C+D M$ & $3.31 \pm 0.14^{++}$ & $4.25 \pm 0.48$ & $3.45 \pm 0.27$ \\
\hline \multicolumn{4}{|c|}{ Content of oxidized form of coenzyme $Q_{10}$ in mitochondria [nmol/mg of protein] } \\
\hline C & $0.207 \pm 0.01$ & $0.278 \pm 0.03^{+}$ & $0.258 \pm 0.01$ \\
\hline$D M$ & $0.259 \pm 0.03$ & $0.291 \pm 0.02$ & $0.291 \pm 0.02$ \\
\hline$R P C$ & $0.255 \pm 0.01$ & $0.247 \pm 0.02$ & $0.213 \pm 0.02$ \\
\hline$R P C+D M$ & $0.248 \pm 0.01$ & $0.324 \pm 0.04$ & $0.263 \pm 0.26$ \\
\hline
\end{tabular}

Results are given as means $\pm \mathrm{SEM} ; \mathrm{n}=8$. DM - diabetic group, $\mathrm{RPC}$ - group with remote ischemic preconditioning, $C$ - control group, $\mathrm{DM}+\mathrm{RPC}$ - group of streptozotocin-induced $\mathrm{d}$. mellitus affected by remote ischemic preconditioning. $* \mathrm{p}<0.05 \mathrm{RPC}$ after $30 \mathrm{~min}$ ischemia vs. C after 30 min ischemia; ${ }^{\#}$ p $<0.05$ DM after 40 min reperfusion vs. C after 40 min reperfusion, \#\# $p<0.01$ RPC after 40 min reperfusion vs. $C$ after 40 min reperfusion. ${ }^{+} p<0.05$ RPC after stabilization perfusion and $C$ after 30 min ischemia vs. $C$ after stabilization perfusion, ${ }^{++} \mathrm{p}<0.01 \mathrm{DM}$ after stabilization perfusion, $\mathrm{RPC}+\mathrm{DM}$ after stabilization perfusion and $\mathrm{C}$ after 30 min ischemia vs. $C$ after stabilization perfusion

\section{Coenzyme Q9-ox}

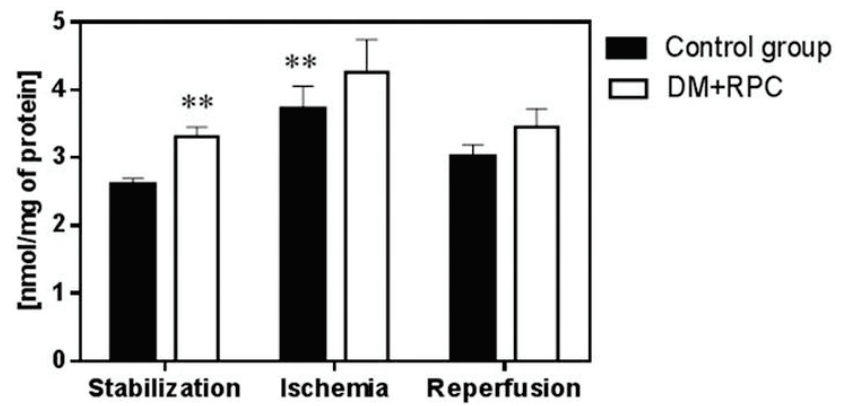

Fig. 3. Effect of DM with RPC on the content of oxidized form of coenzyme $\mathrm{CoQ}_{9-0 x}$. Results are given as means $\pm \mathrm{SEM}, \mathrm{n}=8$. C - control group, DM+RPC - group of streptozotocin-induced d. mellitus affected by remote ischemic preconditioning. ** $\mathrm{p}<0.01 \mathrm{C}$ after $30 \mathrm{~min}$ ischemia and DM+RPC after $15 \mathrm{~min}$ of stabilization perfusion vs. $C$ after 15 min of stabilization perfusion

Membrane fluidity was decreased due to ischemic-reperfusion injury in all groups. DM, RPC and $\mathrm{RPC}+\mathrm{DM}$ prevented the decline observed in the control group. Isolated mitochondrial membranes from diabetic and RPC rat hearts after reperfusion phase exhibited a $5.18 \%(\mathrm{p}<0.01)$ and $1.73 \%$ increase in the membrane lipid fluidity in comparison with control group (Table 2).

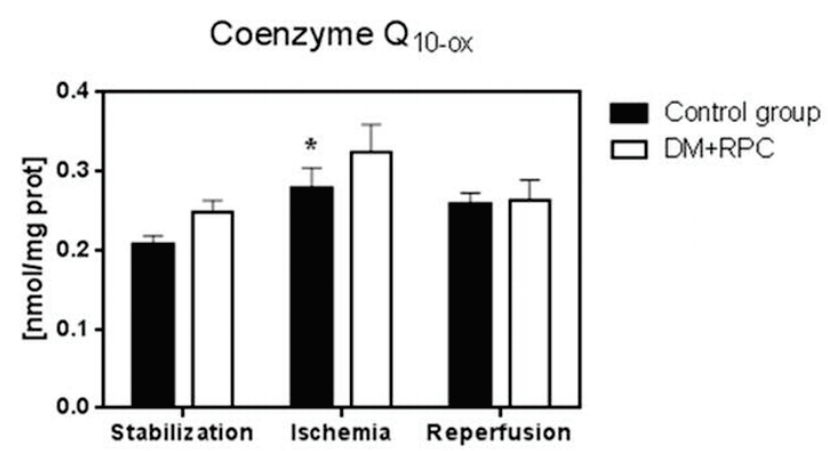

Fig. 4. Effect of DM with RPC on the content of oxidized form of coenzyme $\mathrm{CoQ}_{10-0 x}$. Results are given as means $\pm \mathrm{SEM}, \mathrm{n}=8$. C - control group, DM+RPC - group of streptozotocin-induced d. mellitus affected by remote ischemic preconditioning. $* p<0.05 \mathrm{C}$ after $30 \mathrm{~min}$ ischemia vs. C after $15 \mathrm{~min}$ of stabilization perfusion

RPC $+\mathrm{DM}$ caused a $3.24 \%$ increase in the fluidity of mitochondria isolated from hearts after $40 \mathrm{~min}$ reperfusion (Fig. 2). However, the observed effect did not reach the level of RPC.

We observed a $33.85 \%, 31.54 \%$ and $27.31 \%$ increase in the concentration of $\mathrm{CoQ}_{9-\mathrm{ox}}$ caused by $\mathrm{DM}$, $\mathrm{RPC}$ and $\mathrm{RPC}+\mathrm{DM}$, respectively, in comparison with 
control group after the stabilization perfusion (Table 2, Fig. 3). The content of $\mathrm{CoQ}_{9-0 x}$ was significantly increased (by $43.70 \%$ ) in the control group, while it was not changed in the group of DM, RPC, RPC+DM after the ischemic phase. The ischemic-reperfusion injury had no significant effect on $\mathrm{CoQ}_{9-\mathrm{ox}}$ concentration in the heart mitochondria isolated from control, RPC and RPC+DM group. Unlike these groups, DM group exhibited a significant increase in $\mathrm{CoQ}_{9-\mathrm{ox}}$ concentration under the ischemic-reperfusion condition (Table 2). The similar results were observed in the measurement of $\mathrm{CoQ}_{10-\mathrm{ox}}$ concentration in the mitochondria isolated from heart (Fig. 4).

\section{Discussion}

As it has already been mentioned, impulses such as acute streptozotocin-induced DM and RPC trigger mechanisms of endogenous protection that help reduce myocardial injury caused by ischemia (Birnbaum et al. 1997, Kharbanda et al. 2002, Oxman et al. 1997, Ravingerová et al. 2010, Shi and Vinten-Johansen 2012). These cardioprotective mechanisms have not been fully elucidated, even if they are known to be associated with the changes at the level of mitochondrial membrane (Ferko et al. 2008, Kristiansen et al. 2005, Turrell et al. 2014). Further, there is no unambiguous information about sufficiency of cardioprotection offered by streptozotocin-induced DM and by RPC adaptation processes. Therefore, we aimed to find out the limits of the separate action of DM and RPC and to verify if their effect can be stimulated by each other.

For this purpose we examined the alterations in the fluidity of mitochondrial membranes using a fluorescent probe as a marker of membrane fluidity and in the free radicals production evaluated by the content of oxidized forms $\mathrm{CoQ}_{9-0 x}$ and $\mathrm{CoQ}_{10-0 x}$ in RPC and DM conditions. We were also interested in whether the observed changes would correlate with physiological state of myocardium evaluated by the determination of the infarct size.

After ischemic-reperfusion phase, we observed a significant anti-infarct effect of RPC on the investigated physiological parameters. Similarly, the results from diabetic hearts showed a significant reduction in the infarct size in comparison with the control group. The combination of DM and RPC suppressed the anti-infarct effect, although the size of infarct area was lower than that in the control group not subjected to the RPC. The important finding is that both RPC and DM induced an increased ischemic tolerance to the ischemic-reperfusion injury. Moreover, the acute phase of type I DM was accompanied by an increased tolerance to ischemia. Nevertheless, RPC in diabetic hearts had no notable additive protective effect. We assume that the protective cascade responsible for the RPC was already activated during the acute phase of diabetes and therefore the additional activation RPC could not be so explicit.

In the previous study, it was documented that mitochondria isolated from acute diabetic hearts exhibit increased membrane fluidity (Ferko et al. 2008). The observed membrane fluidization, which can be interpreted as enhanced flexibility of acyl-chains in the hydrocarbon core of lipid bilayer, can be viewed as the process of endogenous protective mechanisms (Ziegelhöffer et al. 2012, Ferko et al. 2008). This finding was associated with an increase in the mitochondrial ATP-synthase activity, in oxidized forms of the coenzyme Q and with a decrease in the basal and ADPstimulated mitochondrial respiration, in the respiratory control index, in the rate of phosphorylation (Ferko et al. 2006) and in the mitochondrial transmembrane potential (Waczulíková et al. 2007). It has been suggested that these alterations participate in the remodeling of mitochondrial membrane, which leads to preservation of myocardial postischemic function. The results of the present study reporting the increased mitochondrial fluidity from acute diabetic hearts exposed to ischemicreperfusion injury are in accordance with the previous suggestion. The improved functional parameters during post-ischemic reperfusion were also confirmed by a study of Muráriková et al. (2013), where a significant increase in the activity of ATP synthase was observed. RPC, as well as DM conditions completely eliminated the significant decrease in mitochondrial membrane fluidity caused by ischemia and postischemic reperfusion. Moreover, the average change in the membrane fluidity caused by RPC was higher in its absolute value than the change caused by DM. We assume that the permanent persistence of myocardium in the state of pseudohypoxia might be associated with the minor fluidising effect of acute streptozotocin-induced DM (Ziegelhöffer et al. 2002, 2009, Williamson et al. 1993). Moreover, DM with RPC did not affect additively, nevertheless their combination evoked a significant increase in mitochondrial membrane fluidity in comparison with the control group.

Our data from all groups exhibited an increase in 
the mitochondrial content of $\mathrm{CoQ}_{9-\mathrm{ox}}$ and $\mathrm{CoQ}_{10-\mathrm{ox}}$ after the stabilization phase, which persisted after the reperfusion phase except for DM group where we found a significantly increased content of the coenzyme. The DM-caused increase in free radical production was moderated by RPC, which was evidenced by a decrease in $\mathrm{CoQ}_{9-\mathrm{ox}}$ and $\mathrm{CoQ}_{10-\mathrm{ox}}$ contents in the heart mitochondria after ischemic-reperfusion injury. However, the increased free radical production was not accompanied with a rigidization of the mitochondrial membrane. It suggests that formed free radicals acted as signal molecules leaving the mitochondria through the chloride channel and triggering the expression of hypoxic genes (Kalakech et al. 2013, Ziegelhöffer et al. 2009).

The results show that the mitochondrial membrane fluidization as a part of the process of endogenous protection is limited and its maximal level was observed in separate action of RPC and DM.

\section{Conclusion}

In general, the concept of fluidity is interpreted as permissiveness of the architecture to continuous, dynamic restructuring of the clusters according to the needs of the cell and as evoked by the alterations in the environment conditions (Vereb et al. 2003). Our findings confirm the positive participation of biophysical membrane remodeling of heart mitochondria in the process of endogenous protection resulting in a partial adaptation to ischemic conditions. The fluidizing effect of the mitochondrial membrane observed in the acute diabetic and RPC cardiac mitochondria appears to be a significant component of cardioprotection. Membrane fluidization facilitates transport of ATP from mitochondria to cytoplasm in the cardiomyocytes. Proven compensatory mechanisms are reflected in the sustained higher capacity of the mitochondria to produce ATP for the increased energy demand during postischemic reperfusion.

Processes of a short-term adaptation such as acute streptozotocin DM and RPC induced a beneficial signal sufficient enough to trigger the process of protection myocardium against ischemic-reperfusion injury. No additive effect was observed in the group subjected to the combination of DM and RPC, which points to the possibility of triggering the same chain of events by both conditions.

\section{Conflict of Interest}

There is no conflict of interest.

\section{Acknowledgements}

The excellent help of Mgr. Veronika LedvényiováFarkašová and valuable technical assistance of Mrs Zlatica Hradecká and Mrs Miroslava Zádorová from Institute for Heart Research, Centre of Excellence SAS NOREG, Slovak Academy of Sciences is gratefully acknowledged. Supported by Grants: VEGA 2/0133/15, 2/0201/15; APVV-0102-11

\section{References}

BAKKER A, DE BIE M, BERNAERT I, RAVINGEROVA T, ZIEGELHÖFFER A, VAN BELLE H, JACOB W: Increased extracellular calcium concentrations in the isolated rat heart: effects on mitochondrial contact site formation. Eur J Morphol 31: 46-50, 1993.

BIRNBAUM Y, HALE SL, KLONER RA: Ischemic preconditioning at a distance: reduction of myocardial infarct size by partial reduction of blood supply combined with rapid stimulation of the gastrocnemius muscle in the rabbit. Circulation 96: 1641-1646, 1997.

FERDINANDY P, HAUSENLOY DJ, HEUSCH G, BAXTER GF, SCHULZ R: Interaction of risk factors, comorbidities, and comedications with ischemia/reperfusion injury and cardioprotection by preconditioning, postconditioning, and remote conditioning. Pharmacol Rev 66: 1142-1174, 2014.

FERKO M, GVOZDJAKOVÁ A, KUCHARSKÁ J, MUJKOSOVÁ J, WACZULÍKOVÁ I, STYK J, RAVINGEROVÁ T, ZIEGELHÖFFER-MIHALOVICOVÁ B, ZIEGELHÖFFER A: Functional remodelling of heart mitochondria in acute diabetes: interrelationships between damage, endogenous protection and adaptation. Gen Physiol Biophys 25: 397-413, 2006.

FERKO M, HABODÁSZOVÁ D, WACZULÍKOVÁ I, MUJKOŠOVÁ J, KUCHARSKÁ J, ŠIKUROVÁ L, ZIEGELHÖFFER B, STYK J, ZIEGELHÖFFER A: Endogenous protective mechanisms in remodeling of rat heart mitochondrial membranes in the acute phase of streptozotocin-induced diabetes. Physiol Res 57 (Suppl 2): S67-S73, 2008. 
FERKO M, KANCIROVÁ I, JAŠOVÁ M, ČARNICKÁ S, MURÁRIKOVÁ M, WACZULÍKOVÁ I, SUMBALOVÁ Z, KUCHARSKÁ J, ULIČNÁ O, RAVINGEROVÁ T, ZIEGELHÖFFER A: Remote ischemic preconditioning of the heart: protective responses in functional and biophysical properties of cardiac mitochondria. Physiol Res 63 (Suppl 4): S469-S478, 2014.

HEUSCH G: Molecular basis of cardioprotection: signal transduction in ischemic pre-, post-, and remote conditioning. Circ Res 116: 674-699, 2015.

INCERPI S, BALDINI P, LULY P: Modulation of human erythrocyte Na-pump by changes of plasma membrane lipid fluidity. In: Advances in Biotechnology of Membrane Ion Transport. PL JORGENSEN, R VERNA (eds), Raven Press, New York, 1988, pp 213-224.

KALAKECH H, TAMAREILLE S, PONS S, GODIN-RIBUOT D, CARMELIET P, FURBER A, MARTIN V, BERDEAUX A, GHALEH B, PRUNIER F: Role of hypoxia inducible factor-1 $\alpha$ in remote limb ischemic preconditioning. J Mol Cell Cardiol 65: 98-104, 2013.

KHARBANDA RK, MORTENSEN UM, WHITE PA, KRISTIANSEN SB, SCHMIDT MR, HOSCHTITZKY JA, VOGEL M, SORENSEN K, REDINGTON AN, MACALLISTER R: Transient limb ischemia induces remote ischemic preconditioning in vivo. Circulation 106: 2881-2883, 2002.

KRISTIANSEN SB, HENNING O, KHARBANDA RK, NIELSEN-KUDSK JE, SCHMIDT MR, REDINGTON AN, NIELSEN TT, BØTKER HE: Remote preconditioning reduces ischemic injury in the explanted heart by a KATP channel-dependent mechanism. Am J Physiol Heart Circ Physiol 288: H1252-H1256, 2005.

KUCHARSKÁ J, GVOZDJAKOVÁ A, ŠNIRCOVÁ M, MIZERA S, BRUNOVÁ Z, SCHRAMEKOVÁ E, SCHREINEROVÁ Z, PECHÁŇ I, FABIÁN J: The assessment of coenzyme Q10 and $\alpha$-tocoferol in patient with cardiomyopathies of unknown origin: prospective diagnostic possibilities. (in Slovak) Bratisl Lek Listy 97: 351-354, 1996.

LIM SY, YELLON DM, HAUSENLOY DJ: The neural and humoral pathways in remote limb ischemic preconditioning. Basic Res Cardiol 105: 651-655, 2010.

LOWRY OH, ROSEBROUGH NJ, FARR AL, RANDALL RJ: Protein measurement with the Folin phenol reagent. J Biol Chem 193: 265-275, 1951.

MASTITSKAYA S, MARINA N, GOURINE A, GILBEY MP, SPYER KM, TESCHEMACHER AG, KASPAROV S, TRAPP S, ACKLAND GL, GOURINE AV: Cardioprotection evoked by remote ischaemic preconditioning is critically dependent on the activity of vagal pre-ganglionic neurones. Cardiovasc Res 95: 487-494, 2012.

MURÁRIKOVÁ M, FERKO M, BARTEKOVÁ M, WACZULÍKOVÁ I, LEDVÉNYIOVÁ V, ČARNICKÁ S, BRUCKNEROVÁ I, RAVINGEROVÁ T, ZIEGELHÖFFER A: Enhanced resistance of the diabetic rat heart to ischemia/reperfusion injury: involvement of mitochondria. Exp Clin Cardiol 18 (Suppl A): 1-5, 2013.

OXMAN T, ARAD M, KLEIN R, AVAZOV N, RABINOWITZ B: Limb ischemia preconditions the heart against reperfusion tachyarrhythmia. Am J Physiol 273: H1707-H1712, 1997.

PRZYKLENK K, WHITTAKER P: Remote ischemic preconditioning: current knowledge, unresolved questions, and future priorities. J Cardiovasc Pharmacol Ther 16: 255-259, 2011.

PRZYKLENK K, BAUER B, OVIZE M, KLONER RA, WHITTAKER P: Regional ischemic 'preconditioning' protects remote virgin myocardium from subsequent sustained coronary occlusion. Circulation 87: 893-899, 1993.

RAVINGEROVÁ T, ŠTETKA R, VOLKOVOVÁ K, PANCZA D, DŽURBA A, ZIEGELHÖFFER A, STYK J: Acute diabetes modulates response to ischemia in isolated rat heart. Mol Cell Biochem 210: 143-151, 2000.

RAVINGEROVÁ T, MATEJÍKOVÁ J, NECKÁR J, ANDELOVÁ E, KOLÁR F: Differential role of PI3K/Akt pathway in the infarct size limitation and antiarrhythmic protection in the rat heart. Mol Cell Biochem 297: 111-120, 2007.

RAVINGEROVÁ T, ADAMEOVÁ A, MATEJíKOVÁ J, KELLY T, NEMČEKOVÁ M, KUCHARSKÁ J, PECHÁŇOVÁ O, LAZOU A: Subcellular mechanisms of adaptation in the diabetic myocardium: relevance to ischemic preconditioning in the nondiseased heart. Exp Clin Cardiol 15: 68-76, 2010.

SHI W, VINTEN-JOHANSEN J: Endogenous cardioprotection by ischaemic postconditioning and remote conditioning. Cardiovasc Res 94: 206-216, 2012. 
SHINITZKY M: Membrane fluidity and cellular functions. In: Physiology of Membrane Fluidity. M. SHINITZKY (ed), CRC Press, Boca Raton, 1984, pp 1-51.

TANI M, NEELY JR: Hearts from diabetic rats are more resistant to in vitro ischemia: possible role of altered $\mathrm{Ca}^{2+}$ metabolism. Circ Res 62: 931-940, 1988.

TOSAKI A, ENGELMAN DT, ENGELMAN RM, DAS DK: The evolution of diabetic response to ischemia/reperfusion and preconditioning in isolated working rat hearts. Cardiovasc Res 31: 526-536, 1996.

TRIBULOVÁ N, RAVINGEROVÁ T, VOLKOVOVÁ K, ZIEGELHÖFFER A, OKRUHLICOVÁ L, ZIEGELHÖFFER B, STYK J, SLEZÁK J: Resistance of diabetic rat hearts to Ca overload-related injury. Histochemical and ultrastructural study. Diabetes Res Clin Pract 31 (Suppl): S113-S122, 1996.

TURRELL HE, THAITIRAROT C, CRUMBIE H, RODRIGO G: Remote ischemic preconditioning of cardiomyocytes inhibits the mitochondrial permeability transition pore independently of reduced calcium loading or sarcKATP channel activation. Physiol Rep 2: pii: e12231, 2014.

VEIGHEY K, MACALLISTER R: Clinical applications of remote ischemic preconditioning. Cardiol Res Pract 2012: Article ID 620681, 2012.

VEREB G, SZÖLLOSI J, MATKÓ J, NAGY P, FARKAS T, VIGH L, MÁTYUS L, WALDMANN TA, DAMJANOVICH S: Dynamic, yet structured: the cell membrane three decades after the Singer-Nicolson model. Proc Natl Acad Sci U S A 100: 8053-8058, 2003.

WACZULÍKOVÁ I, HABODÁSZOVÁ D, CAGALINEC M, FERKO M, ULIČNÁ O, MATEAŠÍK A, ŠIKUROVÁ L, ZIEGELHÖFFER A: Mitochondrial membrane fluidity, potential, and calcium transients in the myocardium from acute diabetic rats. Can J Physiol Pharmacol 85: 372-381, 2007.

WACZULÍKOVÁ I, CAGALINEC M, ULIČNÁ O, SLEZÁK P, ZIEGELHÖFFER A: Biophysical investigation on left ventricular myocytes in rats with experimentally induced diabetes. Physiol Res 59 (Suppl 1): S9-S17, 2010.

WILLIAMSON JR, CHANG K, FRANGOS M, HASAN KS, IDO Y, KAWAMURA T, NYENGAARD JR, VAN DEN ENDEN M, KILO C, TILTON RG: Hyperglycemic pseudohypoxia and diabetic complications. Diabetes 42: 801-813, 1993.

ZIEGELHÖFFER A, RAVINGEROVÁ T, WACZULÍKOVÁ I, ČÁRSKY J, NECKÁR J, ZIEGELHÖFFERMIHALOVICOVÁ B, STYK J: Energy transfer in acute diabetic rat hearts: adaptation to increased energy demands due to augmented calcium transients. Ann N Y Acad Sci 967: 463-468, 2002.

ZIEGELHÖFFER A, WACZULÍKOVÁ I, FERKO M, KINCELOVÁ D, ZIEGELHÖFFER B, RAVINGEROVÁ T, CAGALINEC M, SCHÖNBURG M, ZIEGELHÖFFER T, ŠIKUROVÁ L, ULIČNÁ O, MUJKOŠOVÁ J: Calcium signaling-mediated endogenous protection of cell energetics in the acutely diabetic myocardium. Can J Physiol Pharmacol 87: 1083-1094, 2009.

ZIEGELHÖFFER A, WACZULÍKOVÁ I, FERKO M, ŠIKUROVÁ L, MUJKOŠOVÁ J, RAVINGEROVÁ T: Involvement of membrane fluidity in endogenous protective processes running on subcellular membrane systems of the rat heart. Physiol Res 61 (Suppl 2): S11-S21, 2012.

ZIEGELHÖFFER-MIHALOVIČOVÁ B, OKRUHLICOVÁ L, TRIBULOVÁ N, RAVINGEROVÁ T, VOLKOVOVÁ K, SEBOKOVÁ J, ZIEGELHÖFFER A: Mitochondrial contact sites detected by creatine phosphokinase activity in the hearts of normal and diabetic rats: Is mitochondrial contact sites formation a calcium-dependent process? Gen Physiol Biophys 16: 329-338, 1997.

ZIEGELHÖFFER-MIHALOVIČOVÁ B, WACZULÍKOVÁ I, ŠIKUROVÁ L, STYK J, ČÁRSKY J, ZIEGELHÖFFER A: Remodelling of the sarcolemma in diabetic rat hearts: the role of membrane fluidity. Mol Cell Biochem 249: 175-182, 2003. 